\title{
Kinetics and Mechanism of Paracetamol Oxidation by Chromium(VI) in Absence and Presence of Manganese(II) and Sodiumdodecyl Sulphate
}

\author{
Mohammed Ilyas, ${ }^{1}$ Maqsood Ahmad Malik, ${ }^{1}$ Syed Misbah Zahoor Andrabi, ${ }^{1}$ and Zaheer Khan ${ }^{1,2}$ \\ ${ }^{1}$ Department of Chemistry, Jamia Millia Islamia, Central University, Jamia Nagar, New Delhi 110025, India \\ ${ }^{2}$ Department of Chemistry, Faculty of Science, King Abdulaziz University, P.O. Box 80203, Jeddah 21589, \\ Saudi Arabia
}

Correspondence should be addressed to Zaheer Khan, drkhanchem@yahoo.co.in

Received 24 May 2007; Accepted 6 August 2007

Recommended by Vasudevanpillai Biju

The kinetics of paracetamol oxidation are first order each in [paracetamol] and $\left[\mathrm{HClO}_{4}\right]$. The kinetic study shows that the oxidation proceeds in two steps. The effects of anionic micelles of sodiumdodecyl sulphate (SDS) and complexing agents (ethylenediammine tetraacetic acid (EDTA) and 2,2'-bipyridyl (bpy)) were also studied. Fast kinetic spectrophotometric method has been described for the determination of paracetamol. The method is based on the catalytic effect of manganese(II) on the oxidation of paracetamol by chromium(VI) in the presence of $\mathrm{HClO}_{4}\left(=0.23 \mathrm{~mol} \mathrm{dm}^{-3}\right)$. Optimum reaction time is 4 to 6 minutes at a temperature of $30^{\circ} \mathrm{C}$. The addition of manganese(II) ions largely decreased the absorbance of chromium(VI) at $350 \mathrm{~nm}$. This reaction can be utilized for the determination of paracetamol in drugs.

Copyright (c) 2007 Mohammed Ilyas et al. This is an open access article distributed under the Creative Commons Attribution License, which permits unrestricted use, distribution, and reproduction in any medium, provided the original work is properly cited.

\section{INTRODUCTION}

Spectrophotometric determination of paracetamol in drug formulations has been the subject of several investigators [1-8]. Generally, the same principle, that is, oxidation of paracetamol by metal ion oxidants, has been used for the estimation of paracetamol. The official pharmacopeia [9] and Sultan [10] methods require a 60-minute reflux period and 15 minutes heating of the reaction mixture, respectively. The main disadvantages of the Sultan method are that high concentration $\left(6 \mathrm{~mol} \mathrm{dm}^{-3}\right)$ of sulphuric acid and high temperature $\left(80^{\circ} \mathrm{C}\right)$ are required for the oxidation of paracetamol by chromium(VI).

The kinetic methods of analysis are highly sensitive, selective, simple, accurate, and less expensive. In recent years, several kinetic catalytic techniques have been reported for the detection of biomolecules [11-13]. In search for an alternative to those methods in which high sulphuric acid concentrations are required for paracetamol oxidation by chromium(VI) and to avoid the need for longer heating at higher temperature, complexing agents (man-
ganese(II), EDTA, and bpy) and anionic and cationic surfactants (SDS and CTAB) were added to enhance the decay of chromium(VI) absorbance at $350 \mathrm{~nm}$.

\section{EXPERIMENTAL}

\subsection{Reagents and solutions}

All the reagents were of analytical reagent grade and all the solutions were prepared in doubly distilled (first time from alkaline $\mathrm{KMnO}_{4}$ ) and $\mathrm{CO}_{2}$ free deionized water. A solution of paracetamol (99\%, Acros organics, NJ, USA) $1.0 \times$ $10^{-2} \mathrm{~mol} \mathrm{dm}^{-3}$ was prepared by dissolving $0.151 \mathrm{~g}$ of paracetamol in water, and the solution was diluted to the mark in $100 \mathrm{~cm}^{3}$ volumetric flask. Stock Solutions of potassium dichromate $\left(1.0 \times 10^{-4} \mathrm{~mol} \mathrm{dm}^{-3}\right)$ and manganese(II) chloride $\left(1.0 \times 10^{-2} \mathrm{~mol} \mathrm{dm}^{-3}\right)$, disodium salt of ethylenediamine tetraacetic acid (EDTA) $\left(1.0 \times 10^{-2} \mathrm{~mol} \mathrm{dm}^{-3}\right)$, and sodiumdodecyl sulphate (SDS) $\left(1.0 \times 10^{-2} \mathrm{~mol} \mathrm{dm}^{-3}\right)$ were prepared in a similar manner. The solution of EDTA was stored in a polythene bottle as its solution gradually leaches metal ions 
TABLE 1: Values of pseudo-first-order rate constants for the oxidation of $[\mathrm{PCM}]\left(=1.0 \times 10^{-3} \mathrm{~mol} \mathrm{dm}^{-3}\right)$ by $[\mathrm{Cr}(\mathrm{VI})](=1.0 \times$ $10^{-4} \mathrm{~mol} \mathrm{dm}^{-3}$ ) as a function of [complexing agents] at $30^{\circ} \mathrm{C}$.

\begin{tabular}{llllll}
\hline $\begin{array}{l}10^{4}[\mathrm{Mn}(\mathrm{II})] \\
\left(\mathrm{mol} \mathrm{dm}^{-3}\right)\end{array}$ & $\begin{array}{l}10^{3} k_{\text {obs1 }} \\
\left(\mathrm{s}^{-1}\right)\end{array}$ & $\begin{array}{l}10^{4}[\mathrm{bpy}] \\
\left(\mathrm{mol} \mathrm{dm}^{-3}\right)\end{array}$ & $\begin{array}{l}10^{3} k_{\text {obs2 }} \\
\left(\mathrm{s}^{-1}\right)\end{array}$ & $\begin{array}{l}10^{4}[\mathrm{EDTA}] \\
\left(\mathrm{mol} \mathrm{dm}^{-3}\right)\end{array}$ & $\begin{array}{l}10^{3} k_{\text {obs3 }} \\
\left(\mathrm{s}^{-1}\right)\end{array}$ \\
\hline 7.0 & 1.6 & 10.0 & 2.0 & 10.0 & 3.1 \\
10.0 & 2.0 & 12.0 & 2.0 & 14.0 & 3.9 \\
12.0 & 2.7 & 14.0 & 1.9 & 20.0 & 4.1 \\
15.0 & 3.9 & 20.0 & 1.9 & 26.0 & 4.1 \\
17.0 & 4.7 & 26.0 & 1.9 & 30.0 & 4.2 \\
20.0 & 7.0 & 30.0 & 1.9 & 34.0 & 3.1 \\
- & - & - & - & 36.0 & 3.2 \\
- & - & - & - & 40.0 & 3.6 \\
- & - & - & - & 40.0 & 3.0 \\
- & - & - & - & 50.0 & 3.0 \\
\hline
\end{tabular}

TABle 2: Effect of temperature on the pseudo-first-order rate constants and activation parameters for the oxidation of paracetamol (= $\left.1.0 \times 10^{-3} \mathrm{~mol} \mathrm{dm}^{-3}\right)$ by $[\mathrm{Cr}(\mathrm{VI})]\left(=1.0 \times 10^{-4} \mathrm{~mol} \mathrm{dm}^{-3}\right)$. [SDS] $=10 \times 10^{-3} \mathrm{~mol} \mathrm{dm}^{-3}$.

\begin{tabular}{lcc}
\hline Temperature $^{\circ}(\mathrm{C})$ & $10^{3} k_{\text {obs }}\left(\mathrm{s}^{-1}\right)$ & $10^{3} k_{\text {obs }}\left(\mathrm{s}^{-1}\right)$ \\
Aqueous & SDS \\
\hline 30 & 1.6 & 1.9 \\
35 & 2.2 & 2.3 \\
40 & 2.7 & 3.0 \\
45 & 2.9 & 3.4 \\
50 & 2.8 & 4.0 \\
55 & 3.2 & 4.7 \\
\hline
\end{tabular}

Activation parameters: ${ }^{\mathrm{a}}$

\begin{tabular}{lcc}
$\mathrm{E}_{\mathrm{a}}\left(\mathrm{kJmol}^{-1}\right)$ & 31 & 28 \\
$\Delta \mathrm{H}^{\#}\left(\mathrm{kJmol}^{-1}\right)$ & 29 & 26 \\
$\Delta \mathrm{S}^{\#}\left(\mathrm{JK}^{-1} \mathrm{~mol}^{-1}\right)$ & -298 & -297 \\
\hline
\end{tabular}

${ }^{a}$ With an average linear regression coefficient, $r \geq 0.996$, for all activation parameters.

from glass containers, resulting in a change in the effective [EDTA], and the solution of $\mathrm{K}_{2} \mathrm{Cr}_{2} \mathrm{O}_{7}$ was stored in a dark glass bottle. To maintain hydrogen ion concentration constant, $\mathrm{HClO}_{4}$ (Fisher, $70 \%$ reagent grade) was used.

\subsection{Kinetic measurements}

An aliquot of the components, potassium dichromate and $\mathrm{HClO}_{4}$, was premixed in a three-necked reaction vessel, thermostated in a water bath at $30^{\circ} \mathrm{C}$ for 10 minutes, and the required volume of paracetamol (thermally equilibrated) was directly added to the dichromate solution. The course of the reaction was followed by measuring the absorbance of the unreacted chromium(VI) ion from time to time at $350 \mathrm{~nm}$ against water, using a spectronic $20-\mathrm{D}$ spectrophotometer. The pseudo-first-order rate constants $\left(k_{\mathrm{obs}}, \mathrm{s}^{-1}\right)$ were determined from the linear part of the plots of $\log$ (absorbance) versus time with a fixed-time method. The same procedure was used to calculate the rate constants in presence of $\mathrm{Mn}$ (II), EDTA, bpy, and SDS.

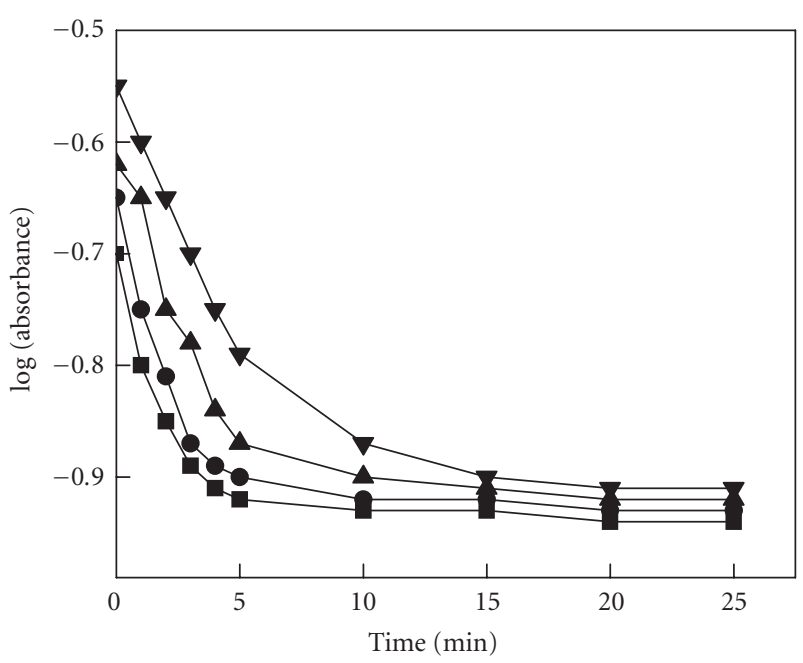

Figure 1: Plots of log (absorbance) versus time for the chromium $(\mathrm{VI})+$ paracetamol reaction. Conditions: $[\mathrm{Cr}(\mathrm{VI})]=$ $1.0 \times 10^{-4} \mathrm{~mol} \mathrm{dm}^{-3} ;\left[\mathrm{HClO}_{4}\right]=0.23 \mathrm{~mol} \mathrm{dm}^{-3}$; temperature $=$ $\left.30^{\circ} \mathrm{C} ; \mathrm{PCM}\right]=1.0(\boldsymbol{\nabla}), 2.0(\mathbf{\Delta}), 3.0(\bullet)$, and $4.0 \times 10^{-3} \mathrm{~mol} \mathrm{dm}^{-3}$ (ם). In case of changing $\left[\mathrm{HClO}_{4}\right]$ and keeping the $[\mathrm{PCM}]=1.0 \times$ $10^{-3} \mathrm{~mol} \mathrm{dm}^{-3}$, similar behavior was observed.

\section{RESULTS AND DISCUSSION}

It is well known that paracetamol undergoes redox reaction with dichromate in presence of higher $\mathrm{H}_{2} \mathrm{SO}_{4}$ amount $\left(6.0 \mathrm{~mol} \mathrm{dm}^{-3}\right)$ to form chromium(III) as the reaction product. This reaction is slow, but is sharply increased by the addition of trace amounts of $\mathrm{Mn}$ (II) and EDTA. Therefore, in order to take full advantage of the role of $\mathrm{Mn}$ (II) and EDTA, the reaction conditions $\left(\mathrm{HClO}_{4}\right.$, concentration, and temperature) and reagent concentrations (dichromate, paracetamol, $\mathrm{Mn}(\mathrm{II})$, and EDTA) must be optimized. Oxidation of paracetamol by dichromate has been studied kinetically as a function of [PCM], [Cr(VI)], [Mn(II)], [EDTA], [bpy], [ $\left.\mathrm{HClO}_{4}\right]$, and [SDS]. The results are compiled in Tables 1-2 and Figures $1-5$.

Figure 1 represents the changes in the log (absorbance) of dichromate with definite time intervals as paracetamol concentrations changes. As the perchloric acid is added, it results in a sudden decrease in the absorbance of dichromate. In order to see the role of $[\mathrm{Mn}(\mathrm{II})]$, a series of kinetic runs were performed under different experimental conditions (Figure 2). The effect of [PCM] on the reaction rate was studied in the absence and presence of SDS anionic micelles. The results show that the $k_{\mathrm{obs}}$ increase with increasing $[\mathrm{PCM}]$ in both media (Figure 3). The effects of $\mathrm{HClO}_{4}$ and temperature on the sensitivity were also studied. Figure 4 shows that the reaction rate increases with $\left[\mathrm{H}^{+}\right]$in absence and presence of SDS micelles. The reaction follows the first, fractional, and first-order kinetics with respect to $[\mathrm{Cr}(\mathrm{VI})]$, $[\mathrm{PCM}]$, and $[\mathrm{Mn}(\mathrm{II})]$, respectively. [EDTA] and [bpy] have zero-order dependence on reaction rate (Table 1). The effect of temperature on the sensitivity was studied in the range 30 $50^{\circ} \mathrm{C}$. The results show that as the temperature increases, the reaction rate increases. The value of activation energy $\left(E_{a}\right)$ 


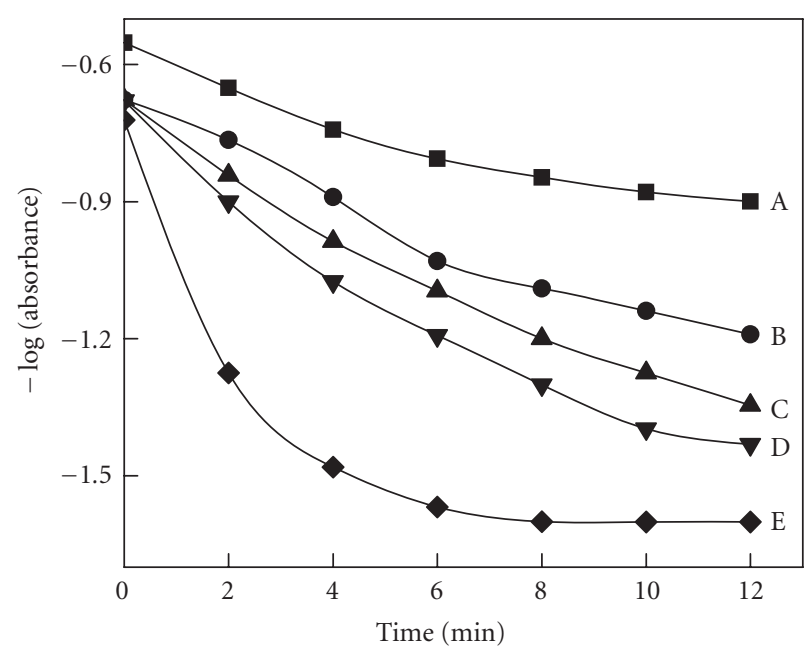

FIgURE 2: Effect of $[\mathrm{Mn}(\mathrm{II})]$ on the plot of log (absorbance) versus time. Conditions: $[\mathrm{Cr}(\mathrm{VI})]=1.0 \times 10^{-4} \mathrm{~mol} \mathrm{dm}^{-3}$; $\left[\mathrm{HClO}_{4}\right]$ $=0.23 \mathrm{~mol} \mathrm{dm}^{-3} ;[\mathrm{PCM}]=1.0 \times 10^{-3} \mathrm{~mol} \mathrm{dm}^{-3}$; temperature $=$ $30^{\circ} \mathrm{C} ;[\mathrm{Mn}(\mathrm{II})]=(\mathrm{A}) 0.0,(\mathrm{~B}) 1.0,(\mathrm{C}) 1.2$, (D) 1.4 , and (E) $2.0 \times$ $10^{-3} \mathrm{~mol} \mathrm{dm}^{-3}$.

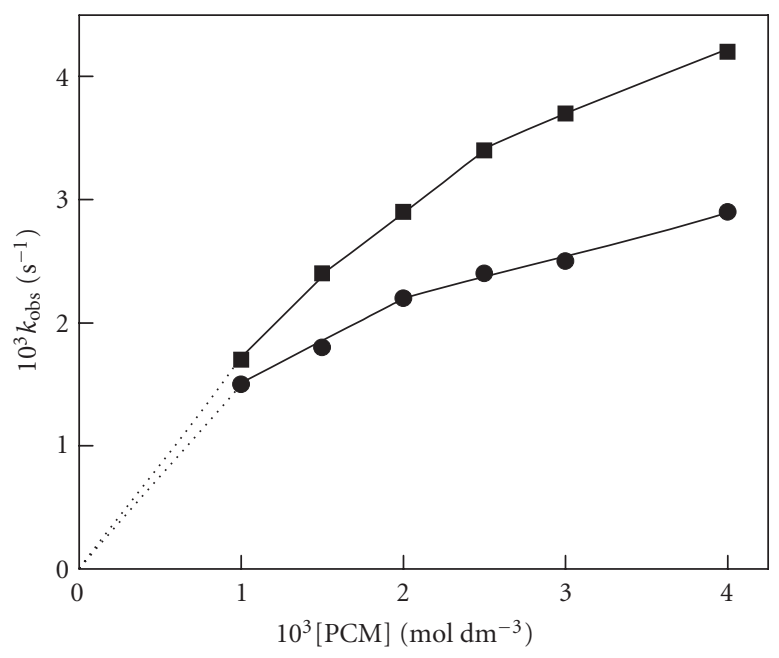

FIgURE 3: Effect of $[\mathrm{PCM}]$ on $k_{\text {obs }}$ in absence $(\bullet)$ and presence $(\mathbf{\square})$ of SDS. Conditions: $[\mathrm{Cr}(\mathrm{VI})],\left[\mathrm{HClO}_{4}\right]$, and temperature were the same as in Figure 1. [SDS] $=10.0 \times 10^{-3} \mathrm{~mol} \mathrm{dm}^{-3}$.

was calculated from the slope of Arrhenius plots (Table 2). The observation is consistent with the accepted view that a slow reaction would require a higher energy of activation.

On the basis of above results, Scheme 1 has been proposed for the oxidation of paracetamol by chromium(VI).

In Scheme 1, the reactive species of $\mathrm{Cr}(\mathrm{VI})$ and paracetamol readily form chromate ester as the first step in the reduction of $\mathrm{Cr}(\mathrm{VI})$ [14]. Chromate ester undergoes oxidative decomposition in the next step (rate determining), leading to the formation of an intermediate and $\mathrm{Cr}(\mathrm{IV})$ [15]. The proposed mechanism is further supported by analysis of the products. Ammonia has been detected as ammonium ions in aqueous solution. Benzoquinone and acetic acid were also detected by the spot tests [16]. Similar products using

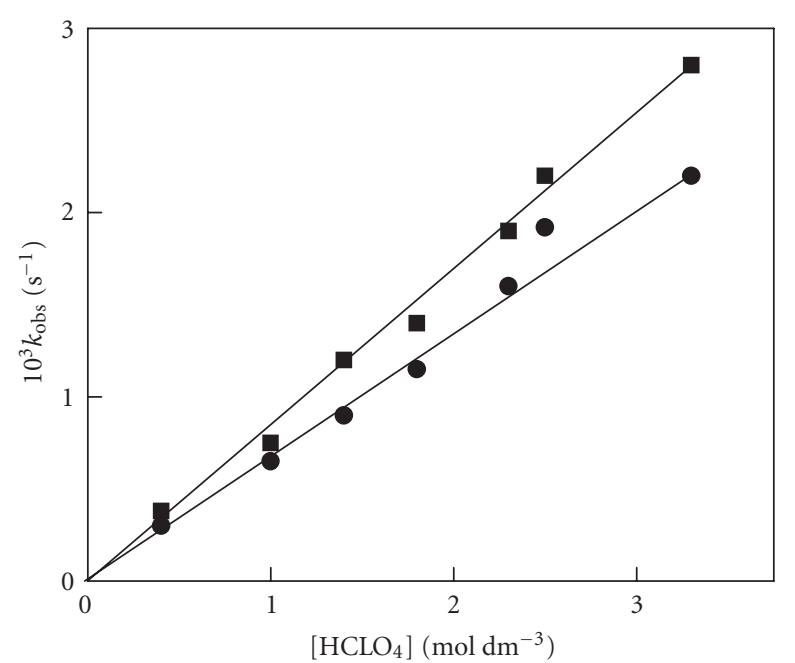

FIGURE 4: Effect of $\left[\mathrm{HClO}_{4}\right]$ on $k_{\text {obs }}$ in absence $(\bullet)$ and presence (ם) of SDS. Conditions: $[\mathrm{Cr}(\mathrm{VI})]=1.0 \times 10^{-4} \mathrm{~mol} \mathrm{dm}^{-3} ;[\mathrm{PCM}]=$ $1.0 \times 10^{-3} \mathrm{~mol} \mathrm{dm}^{-3}$; [SDS $]=10.0 \times 10^{-3} \mathrm{~mol} \mathrm{dm}^{-3}$; temperature $=$ $30^{\circ} \mathrm{C}$.

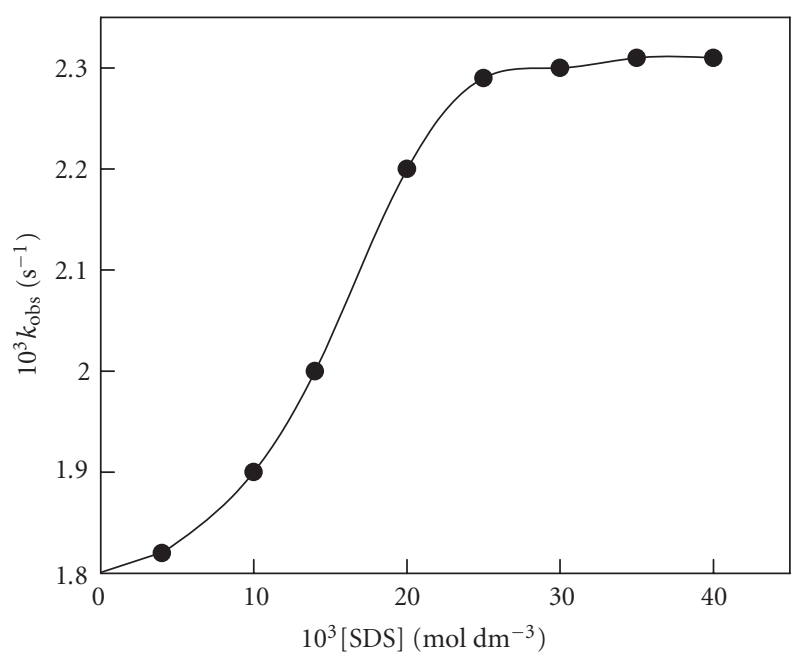

FIGURE 5: Effect of [SDS] on $k_{\text {obs }}$. Other reaction conditions were the same as in Figures 1 and 2.

the same oxidant have been also suggested by Sultan [10]. The positive catalytic effect of $\mathrm{Mn}$ (II) (Table 1) is due to a one-step three-electron oxidation of paracetamol directly to chromium(III). One of the electrons transferred is donated by manganese(II) atom and the other two by paracetamol. The observed catalytic effect rules out the possibility of chromium(IV) formation in the rate-determining step $[17,18]$. In presence of $\mathrm{Mn}(\mathrm{II})$, Scheme 1 mechanism can be modified to Scheme 2.

In presence of $\mathrm{Mn}(\mathrm{II})$, the reaction proceeds through the formation of a termolecular complex between $\mathrm{Cr}(\mathrm{VI})$, paracetomal, and $\mathrm{Mn}$ (II) (Scheme 2) [19] because the direct oxidation of $\mathrm{Mn}$ (II) by chromium(VI) is thermodynamically unfavorable [20]. The positive catalytic effect of $\mathrm{Mn}(\mathrm{II})$ is due to a one-step three-electron reduction of chromium(VI), which is in conformity the reduction of $\mathrm{Cr}(\mathrm{VI}) \rightarrow \mathrm{Cr}(\mathrm{III})$ 


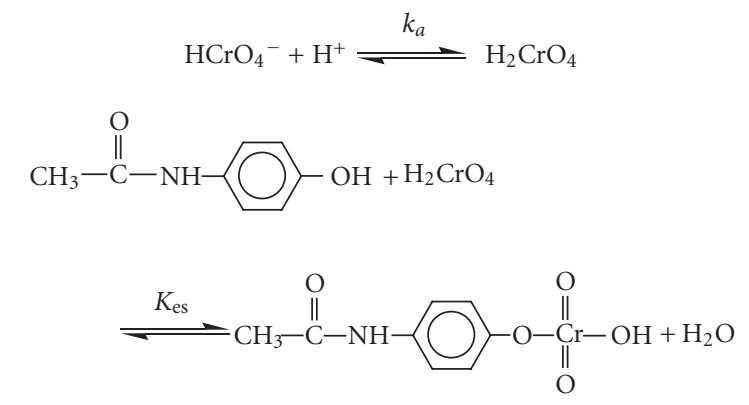

(Chromate ester)

Chromate ester $+\mathrm{H}_{2} \mathrm{O} \stackrel{\text { Slow, } k}{\longrightarrow} \mathrm{CH}_{3}-\stackrel{\mathrm{C}}{\mathrm{C}}-\mathrm{N}=\mathrm{O}+\mathrm{Cr}(\mathrm{IV})$

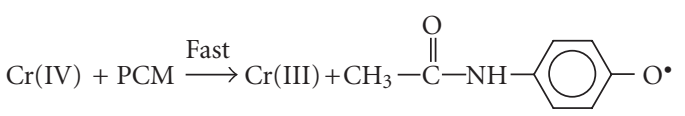

Radical

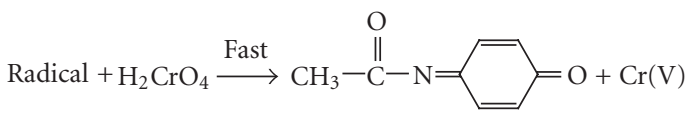

$\mathrm{Cr}(\mathrm{V})+\mathrm{PCM} \stackrel{\text { Fast }}{\longrightarrow} \mathrm{Cr}(\mathrm{III})+\mathrm{CH}_{3}-\stackrel{\mathrm{O}}{\mathrm{C}}-\mathrm{N}=\mathrm{O}$

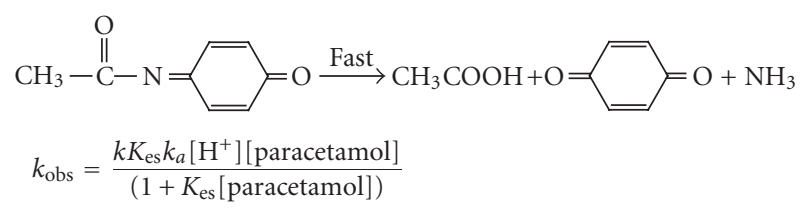

SCHEME 1

$\mathrm{Mn}(\mathrm{II})+$ paracetamol $+\mathrm{H}_{2} \mathrm{CrO}_{4}$ $\stackrel{K_{\mathrm{es} 1}}{\rightleftharpoons} \mathrm{H}_{2} \mathrm{CrO}_{4}-$ paracetamol $-\mathrm{Mn}(\mathrm{II})$ (Complex 1)

$$
\begin{gathered}
\text { Complex } 1 \stackrel{\text { Slow, } k_{1}}{\longrightarrow} \mathrm{CH}_{3}-\stackrel{\mathrm{O}}{\mathrm{C}}-\mathrm{N}=\mathrm{O}+\mathrm{Cr}(\mathrm{III})+\mathrm{Mn}(\mathrm{III}) \\
k_{\mathrm{obs}}=\frac{k_{1} K_{\mathrm{es} 1} k_{a}\left[\mathrm{H}^{+}\right][\text {paracetamol }][\mathrm{Mn}(\mathrm{II})]}{\left(1+K_{\mathrm{es}}[\text { paracetamol }]\right)}
\end{gathered}
$$

SCHEME 2

without passing through formation of $\mathrm{Cr}(\mathrm{IV})$ as an intermediate. Table 1 shows the effect of EDTA and bpy on the reaction rate. It was found that whereas the reduction of paracetamol by chromium(VI) is slow, reduction in presence of EDTA/bpy at a similar concentration is fairly fast. It should be emphasized here that the complexing agents (EDTA and bpy) themselves are resistant to oxidation under the exact conditions employed. Addition of even small quan-

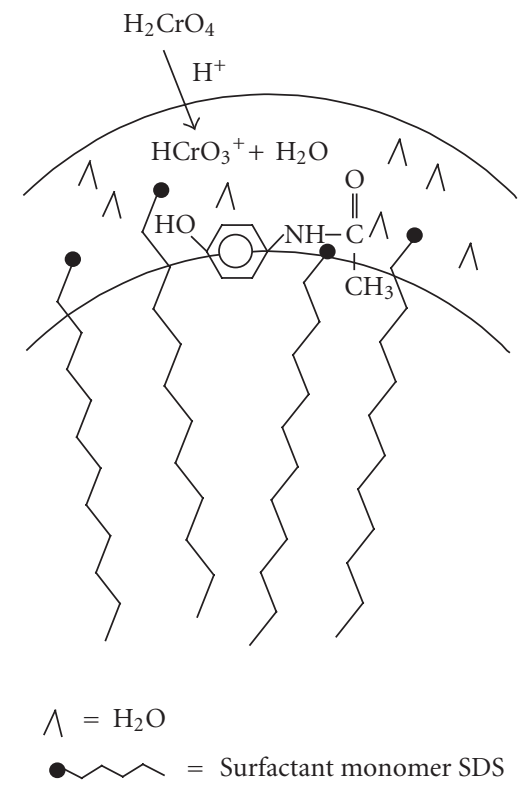

Scheme 3

tity of these complexing agents gives a pronounced rate enhancement. EDTA gives a higher rate than bpy for the same concentrations.

Micellar catalysis has received considerable attention in view of the analogies drawn between micellar and enzyme catalyses [21, 22]. Micelles increase rates of bimolecular reactions by concentrating both the reactants at their surfaces. Electrostatic-, approximation-, and medium-effects are responsible for the incorporation of reactants into or onto a micelle. In order to verify the role of micelles on the paracetamol oxidation by chromium(VI), cationic and anionic micelles were chosen. Preliminary observations showed that a reaction mixture containing chromium(VI) (= $\left.1.0 \times 10^{-4} \mathrm{~mol} \mathrm{dm}^{-3}\right)$, paracetamol $\left(=1.0 \times 10^{-3} \mathrm{~mol} \mathrm{dm}^{-3}\right)$, $\mathrm{HClO}_{4}\left(=0.23 \mathrm{~mol} \mathrm{dm}{ }^{-3}\right)$, and cationic micelles of CTAB became turbid. Therefore, the investigation was confined to verify the effect of anionic SDS micelles. $\mathrm{HClO}_{4}$ is a strong acid which completely dissociates in $\mathrm{H}^{+}$and $\mathrm{ClO}_{4}^{-}$. In presence of cationic surfactant (CTAB), there are electrostatic interactions between the positive head group of cationic micelles and perchlorate ions, which form water insoluble species.

Figure 5 shows the effect of SDS anionic micelles on the sensitivity for the range $5.0 \times 10^{-3} \mathrm{~mol} \mathrm{dm}^{-3}$ to $40.0 \times$ $10^{-3} \mathrm{~mol} \mathrm{dm}^{-3}$. The reaction rate increases with increasing [SDS] up to $\geq 30.0 \times 10^{-3} \mathrm{~mol} \mathrm{dm}^{-3}$ and remains constant at higher [SDS]. This may be due to the dilution effect. Therefore, a final [SDS] of $30.0 \times 10^{-3} \mathrm{~mol} \mathrm{dm}^{-3}$ was chosen as the optimum concentration. The role of SDS micelles in catalysis can be explained by incorporation/solubilizition of chromium(VI)/paracetamol in the Stern layer of SDS micelles through electrostatic and hydrophobic interactions (Scheme 3). These results are in good agreement with our previous observations [23]. 


\section{CONCLUSION}

Although a number of spectrophotometric methods are available for the determination of paracetamol, these are generally associated with some or the other demerits. The use of chromium(VI) for the determination of paracetamol has been suggested but the reaction requires a high concentration of $\mathrm{H}_{2} \mathrm{SO}_{4}$ and very high temperature for the complete consumption of chromium(VI). The results from this study show that oxidation of paracetamol by $\mathrm{Cr}(\mathrm{VI})$ is enhanced in presence of complexing agents (Mn(II), EDTA, and bpy) and surfactant. Of these, $\mathrm{Mn}$ (II) is the most effective as only 5-10 minutes are required for the completion of the reaction. This is very significant for any industrial use to avoid or minimize the use of higher acid concentrations. The present method is simple, accurate, rapid, economical, and precise.

\section{REFERENCES}

[1] J. E. Wallace, "Determination of ephedrine and certain related compounds by ultraviolet spectrophotometry," Analytical Chemistry, vol. 39, no. 4, pp. 531-533, 1967.

[2] F. M. Plakogiannis and A. M. Saad, "Spectrophotometric determination of acetaminophen and dichloralantipyrine in capsules," Journal of Pharmaceutical Sciences, vol. 64, no. 9, pp. 1547-1549, 1975.

[3] K. K. Verma, A. K. Gulati, S. Palod, and P. Tyagi, "Spectrophotometric determination of paracetamol in drug formulations with 2-iodylbenzoate," The Analyst, vol. 109, no. 6, pp. 735737, 1984.

[4] S. M. Sultan, I. Z. Alzamil, A. M. Aziz Alrahman, S. A. Altamrah, and Y. Asha, "Use of cerium(IV) sulphate in the spectrophotometric determination of paracetamol in pharmaceutical preparations," The Analyst, vol. 111, no. 8, pp. 919-921, 1986.

[5] F. A. Mohamed, M. A. AbdAllah, and S. M. Shammat, "Selective spectrophotometric determination of $p$-aminophenol and acetaminophen," Talanta, vol. 44, no. 1, pp. 61-68, 1997.

[6] J. F. van Staden and M. Tsanwani, "Determination of paracetamol in pharmaceutical formulations using a sequential injection system," Talanta, vol. 58, no. 6, pp. 1095-1101, 2002.

[7] M. Oliva, R. A. Olsina, and A. N. Masi, "Selective spectrofluorimetric method for paracetamol determination through coumarinic compound formation," Talanta, vol. 66, no. 1, pp. 229-235, 2005.

[8] M. K. Srivastava, S. Ahmad, D. Singh, and I. C. Shukla, "Titrimetric determination of dipyrone and paracetamol with potassium hexacyanoferrate(III) in an acidic medium," The Analyst, vol. 110, no. 6, pp. 735-737, 1985.

[9] British Pharmacopoeia, Her Majesty's Stationery Office, London, UK, 1980.

[10] S. M. Sultan, "Spectrophotometric determination of paracetamol in drug formulations by oxidation with potassium dichromate," Talanta, vol. 34, no. 7, pp. 605-608, 1987.

[11] S. T. Nandibewoor and V. A. Morab, "Chromium(III)catalysed oxidation of antimony(III) by alkaline hexacyanoferrate(III) and analysis of chromium(III) in microamounts by a kinetic method," Journal of the Chemical Society, Dalton Transactions, no. 3, pp. 483-488, 1995.

[12] T. F. Imdadullah and T. Kumamaru, "Catalytic effect of rhodium(III) on the chemiluminescence of luminol in reverse micelles and its analytical application," Analytica Chimica Acta, vol. 292, no. 1-2, pp. 151-157, 1994.
[13] A. A. Ensafi and M. Keyvanfard, "Kinetic spectrophotometric method for the determination of rhodium by its catalytic effect on the oxidation of o-toluidine blue by periodate in micellar media," Journal of Analytical Chemistry, vol. 58, no. 11, pp. 1060-1064, 2003.

[14] F. H. Westheimer, "The mechanisms of chromic acid oxidations," Chemical Reviews, vol. 45, no. 3, pp. 419-451, 1949.

[15] Z. Khan, P. Kumar, and Kabir-ud-Din, "Kinetics and mechanism of the reduction of colloidal manganese dioxide by Dfructose," Colloids and Surfaces, vol. 248, no. 1-3, pp. 25-31, 2004.

[16] F. Feigl, Spot Tests in Organic Analysis, Elsevier, New York, NY, USA.

[17] C. F. Huber and G. P. Haight Jr., "The oxidation of manganese(II) by chromium(VI) in the presence of oxalate ion," Journal of the American Chemical Society, vol. 98, no. 14, pp. 4128-4131, 1976.

[18] Z. Khan, M. Y. Dar, P. S. S. Babu, and Kabir-ud-Din, "A kinetic study of the reduction of chromium(VI) by thiourea in the absence and presence of manganese(II), cerium(IV) and ethylenediaminetetra acetic acid (EDTA)," Indian Journal of Chemistry, vol. 42A, no. 5, pp. 1060-1065, 2004.

[19] Kabir-ud-Din, K. Hartani, and Z. Khan, "Co-oxidation of malic acid and manganese(II) by chromium(VI) in the presence and absence of ionic surfactants," Indian Journal of Chemistry, vol. 41B, no. 12, pp. 2614-2624, 2002.

[20] J. F. Perez-Benito and C. Arias, "A kinetic study on the reactivity of chromium(IV)," Canadian Journal of Chemistry, vol. 71, no. 5, pp. 649-655, 1993.

[21] F. M. Menger and C. E. Portnoy, "Chemistry of reactions proceeding inside molecular aggregates," Journal of the American Chemical Society, vol. 89, no. 18, pp. 4698-4703, 1967.

[22] C. A. Bunton and G. Savelli, "Organic reactivity in aqueous micelles and similar assemblies," Advances in Physical Organic Chemistry, vol. 22, pp. 213-309, 1986.

[23] Kabir-ud-Din, A. M. A. Morshed, and Z. Khan, "Influence of sodium dodecyl sulfate/TritonX-100 micelles on the oxidation of $\mathrm{D}$-fructose by chromic acid in presence of $\mathrm{HClO}_{4}$," Carbohydrate Research, vol. 337, no. 17, pp. 1573-1583, 2002. 


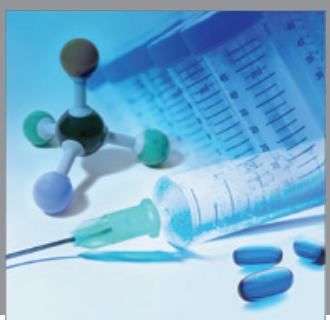

International Journal of

Medicinal Chemistry

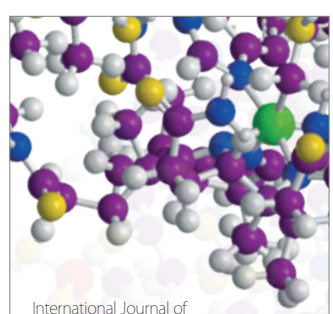

Carbohydrate Chemistry

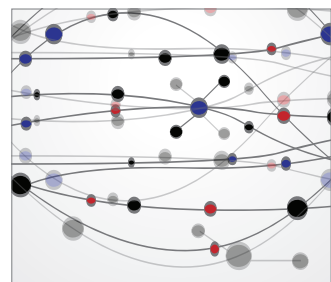

The Scientific World Journal
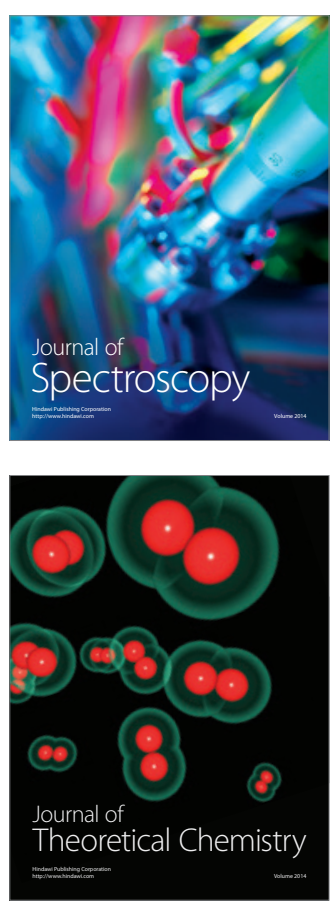
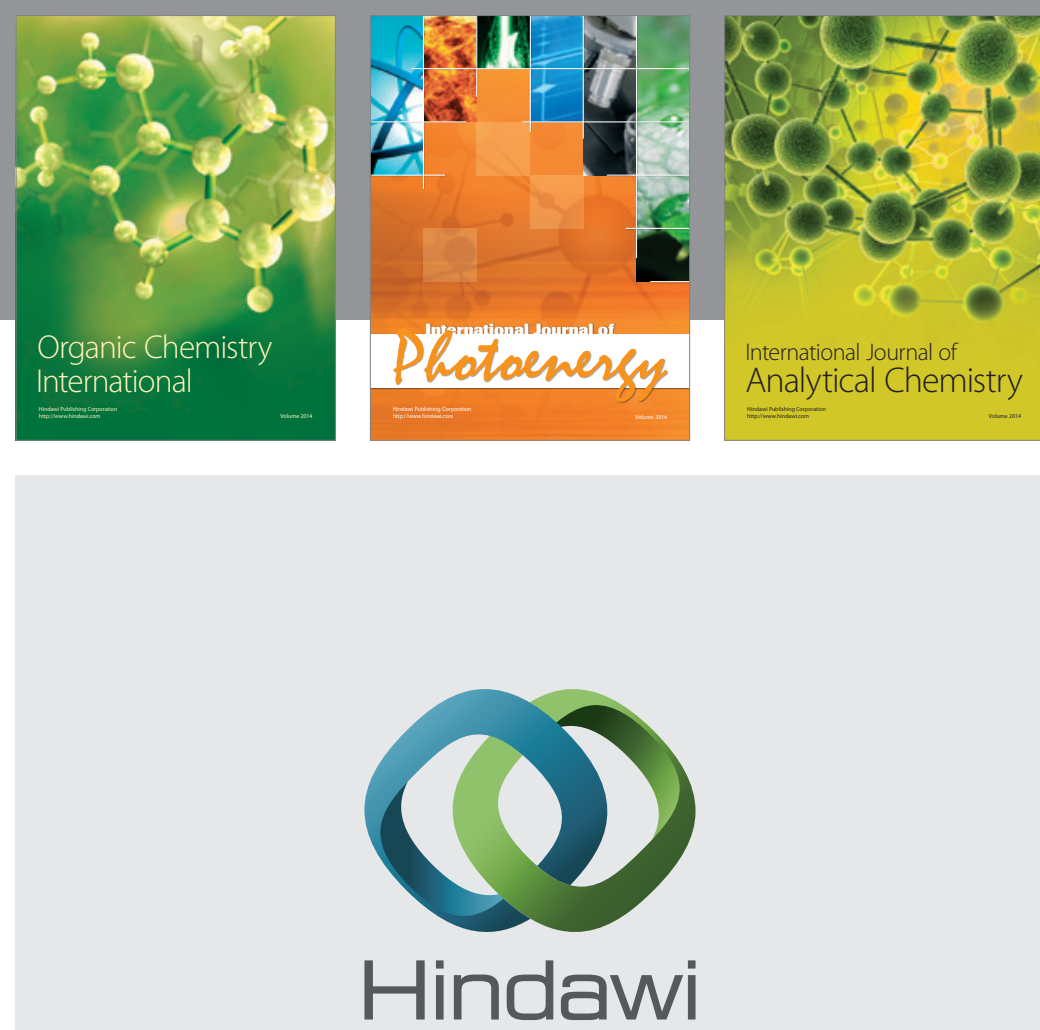

Submit your manuscripts at

http://www.hindawi.com
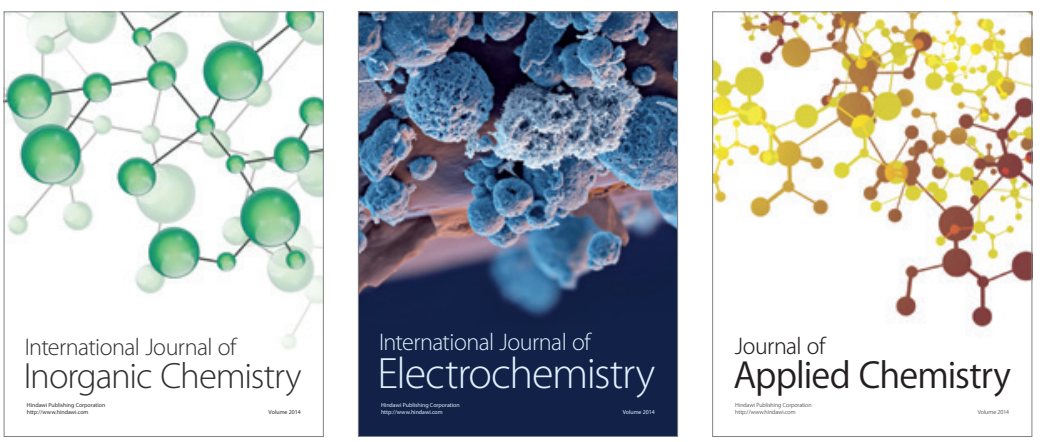

Journal of

Applied Chemistry
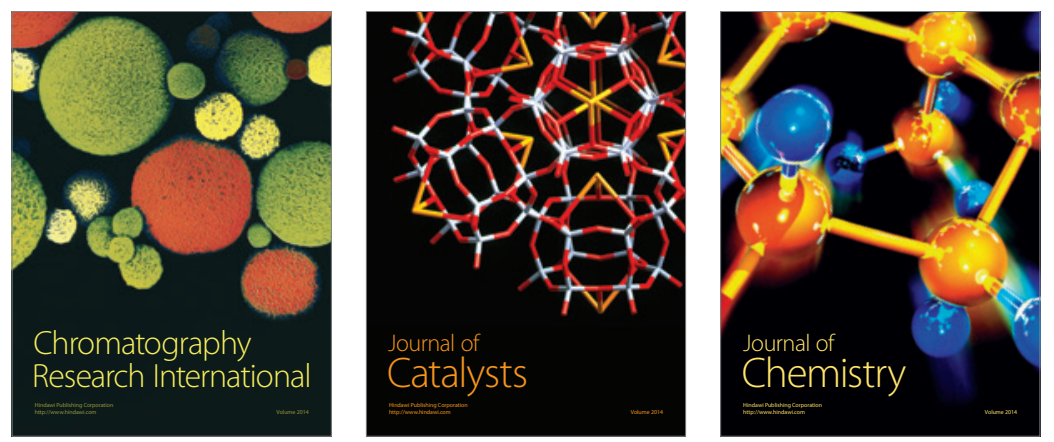
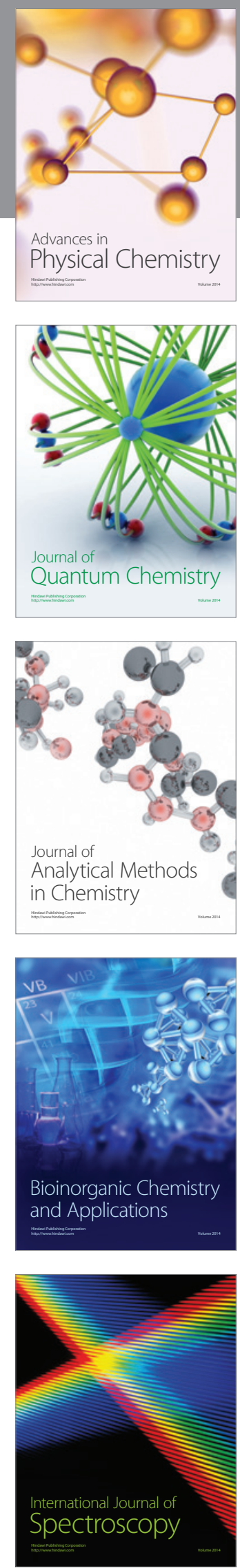